\title{
Competitive Position of the Most Admired Companies 2018 in Consumer Goods Category
}

\author{
Friska Sipayung, Liasta Ginting, Magdalena Linda Leonita Sibarani
}

\begin{abstract}
The Warta Economic Intelligence Unit (WEIU) conducts research in 2018. The research team uses the desk research and quantitative research methods. This research produces the names of companies with the highest awareness and the best image based on the perceptions of respondents as the desired company. Referring to (1) the opinion of David (2016:11), obtaining and maintaining competitive advantage is very important for the long-term success of the organization. (2)Solihin's opinion (2012:25) through strategic decisions made by company management, it will ensure the maintenance of the company's competitive advantage, so the researchers suspect that the success of the Consumer Goods companies in Indonesia Most Admired Companies (IMAC-2018) is due to the right strategy decisions. Regarding IMAC-2018 Consumer Goods Category, this study aims to identify and analyze competitive positions based on financial performance in the Consumer Goods industry, 2)formulate strategies that can be carried out to improve competitive positions in the Consumer Goods industry. To achieve this goal, the research approach used is a combination of qualitative and quantitative approaches with a strategic management design model. The data used in this study are secondary data, namely the financial statements of consumer goodscompany in 2016, 2017 and 2018. This research was conducted in the Top Five Indonesia Most Admired Companies 2018 in Consumer Goods Category, namely PT Garuda Food, PT GudangGaram, PT Nestlé Indonesia, PT Indofood and PT Unilever Indonesia.The results show that 1)the financial performance of PT Unilever Indonesia, shows the best position compared to the others. 2)the strategies chosen based on competitive conditions are aggressive and defensive strategies.
\end{abstract}

Keywords: company strategy, competitive position, financial performance

\section{INTRODUCTION}

Every organization whether profit-oriented or not, product-oriented, service oriented, government, private or even sports, must formulate and implement the right strategies to succeed. Besides that the internal and external business environment that is very dynamic and complex also requires the right business strategy to maintain the existence of the company.This complexity will have implications for the increasingly difficult and complicated decision making process. A good attack without good defense, or vice versa, usually results in defeat. Developing ideas that use power to seize opportunities can be considered an attack, while strategies designed to correct weaknesses and avoid threats can be called defense.
The competition provides a reason for the need for a strategy. Every strategy always requires a review and maybe even a change in the future. One of the

main reasons why this is because the conditions faced by the company both internally and externally are also constantly changing. Assessment carried out simultaneously on the external environment and company profile allows management to identify various types of opportunities which may arise and can be used. A reliable, precise and precise strategy is one of the conditions for the sustainability of the company's business activities. For this reason, analysis and formulation of strategies is one of the main activities for management. Likewise with consumer goods company. To be able to maintain their existence in the face of competition in the global economy; with high levels of complexity, of course, from time to time must formulate the right strategy. The right strategy formulation is inevitable so that the company still exists today and in the future. The Economic Intelligence Unit (WEIU) conducted research in 2018. The research team used the desk research and quantitative research methods. The desks research then produces selected company nominations that will be assessed by respondents in quantitative research. This research generates the names of the companies with the highest awareness and the best image based on the perceptions of respondents as the desired company. Referring to (1) the opinion of David (2016:11), obtaining and maintaining competitive advantage is very important for the long-term success of the organization. (2) the opinion of Solihin (2012:25) through strategic decisions made by company management, will guarantee the maintenance of competitive advantage the company, the researchers suspect that the success of the consumer goods companies that entered the Indonesia Most Admired Companies (IMAC) 2018 was due to the right strategy decision. Based on this explanation, this curiosity was then followed up by conducting research on the Top four Most Admired Companies 2018 in Consumer Goods Category namely PT.Garuda Food Putra Putri Jasa, PT.Gudang Garam, PT. Indo Food Sukses Mandiri and PT. Unilever Indonesia. Based on the background that has been described, then the purpose of this study are: knowing and analyzing the competitive position of the consumer goods company, knowing and analyzing the right strategy for the company, whether aggressive, competitive, conservative and defensive. Sumatera Utara, Medan, Indonesia

Liasta Ginting, Faculty of Economics and Business, Universitas Sumatera Utara, Medan, Indonesia

Magdalena Linda Leonita Sibarani, Faculty of Economics and Business, Universitas Sumatera Utara, Medan, Indonesia 


\section{LITERATURE REVIEW}

\subsection{Strategy and Strategy Formulation}

In essence there is no organization that has unlimited resources, the strategists must decide which alternative strategy will benefit the company the most. The decision formulation strategy encourages an organization to commit to specific products, markets, resources and technology over a long period of time.Long-term competitive determining strategy. David (2012) states that, important strategy formulation techniques can be integrated into a decision making framework with a matrix as a model of analysis. Tools in this framework can be applied to all sizes and types of organizations and can help the strategists identify, evaluate and choose the most appropriate strategy. Some of these techniques include SWOT-Matrix, SPACE-Matrix, BCG-Matrix, IE-Matrix, and Grand Strategy-Matrix. In this study, the position analysis framework and strategy formulation used are the Strategic Position and Action Evaluation Matrix (SPACE-Matrix). Marrus (in Umar, 2008) defines strategy as a process of determining the plans of top leaders who focus on the long-term goals of the organization, along with the preparation of a way or effort to achieve that goal. In addition, Hamel and Prahalad (Umar, 2008) define the strategy as follows: Strategy is an action that is incremental and continuous, and is based on the point of view of what is expected by customers in the future. In this study we will discuss the analysis and choice of main or main strategies. There are several models for determining the main strategies for example based on the approach used by Hunger, David and others. However, the discussion in this study is limited to only the concepts put forward by David. According to David (2016:323) that strategy formulation techniques can be integrated into a three-stage decision making framework with a matrix as the analysis model (Figure 2.1).

\begin{tabular}{|c|c|c|c|c|c|}
\hline \multicolumn{6}{|c|}{ 1:INPUT STAGE } \\
\hline \multicolumn{2}{|c|}{$\begin{array}{l}\text { External Factor } \\
\text { Evaluation } \\
\text { (EFE-Matrix) }\end{array}$} & \multicolumn{2}{|c|}{$\begin{array}{l}\text { Competitive } \\
\text { Profile } \\
\text { (CPM-Matrix) }\end{array}$} & \multicolumn{2}{|c|}{$\begin{array}{l}\text { Internal Factor } \\
\text { Evaluation } \\
\text { (IFE-Matrix) }\end{array}$} \\
\hline \multicolumn{6}{|c|}{ 2:MATCHING STAGE } \\
\hline Strengths- & & & Boston & Internal- & Grand \\
\hline Weaknesses- & & & Consulting & External & Strateg \\
\hline Opportunities & and & & Group & (IE-Matrix & $\mathrm{y}$ \\
\hline - Threats & & & (BCG-Matrix & ) & Matrix \\
\hline & & & MANYY & AG & \\
\hline
\end{tabular}

Source: David, 2016:324

Figure 2.1. Framework Strategy Formulation Analysis

\subsection{Strategic Position and Action Evaluation Matrix (SPACE-Matrix)}

This SPACE matrix is more comprehensive in assessing a company both internal and external factors. This matrix is a four quadrant framework that shows whether the aggressive, conservative, defensive and competitive strategies is the most suitable for a particular organization. SPACE-Matrix is presented in the following figure.



Source: David, 2016:333

Figure 2.2. Strategic Position and Action Evaluation Matrix (SPACE-Matrix)

\subsection{Position of Business Competition}

Pitelis in Kuntjoroadi (2009) "competitiveness" is both elusive and controversial, while Porter (1993) states that competition is the essence of success. In order to win every competition, every company must have a competitive strategy. The ultimate goal of a competitive strategy is to tackle environmental forces in the interests of the company. Assessing competitive positions can increase a company's opportunity to design strategies that optimize opportunities that arise from the environment. The development of competitor profiles allows a company to estimate more accurately both short and long-term growth potential and potential profits. Although the exact criteria used in compiling a competitor's profile are largely determined by situation factors. Some criteria that can be used include: market share, product line width, sales distribution effectiveness, excellence in terms of mastering important customer relationships; price competitiveness, advertising and promotion effectiveness, location and age of facilities, capacity and productivity, experience, financial position, relative quality of products, $R \& D$ position, quality of human resources, image in general.

Setiawan, (2001) in his research entitled the formulation of the corporate strategy of the banking sector by using the space (strategic position \& action evaluation) method and general electric matrix (case study of PT. East Java Regional Development Bank). Concluded that this banking company was in a profile conservative organization. Where the company has a financial advantage supported by a stable business environment, but with a high-level of competition. For this reason, the company should cut the product line, reduce costs, focus on improving the company's cash flow, protect competitive products, develop new products, and immediately take advantage of a very attractive market. Then, from the GE Matrix results obtained that the company has a high industrial attractiveness with a weighted total score of 4.005 (scale 5) and medium business strength with a weighted total score of 3.029 (Scale 5).

Putra, Laurentius and Sendy Agusta (2012) in their research entitled Competing Strategies Using Space Matrix Analysis. Concluding that, external factors stability of the industrial environment are in fairly good condition, and external factors are not good enough, internal factors. Primagama English's competitive advantages are in good condition, and the internal factors of Primagama English's financial strength are in poor condition. 
The SPACE Matrix analysis of Primagama English based on the SPACE Matrix quadrant mapping results in an aggressive type of strategy. While Sukaris, Mochamad Saleh (2008) in the study entitled SPACE Matrix Analysis. In the formulation of business strategies in the Gresik Sector PLN Coopetive, concluded that; sharpening the formulation of the business strategy in the Gresik Sector PLN Cooperative is an aggressive action for a combination of market penetration, market development and creating new products. Information that can be given by researchers to the object of research in formulating future business strategies by establishing a practice of general practitioners/specialists, enhancing customer-oriented services, partnering with other companies.

In this research, the position of business competition is obtained by Competitive Positioning Mapping method with help with Microsoft Excel software. The position of business competition in this study was also identified through company performance. The concept of performance can be defined as an achievement result or degree of accomplishment (Grant, 2009). This means that, the performance of an organization can be seen from the degree to which the organization can achieve goals based on the objectives that have been previously set. Information about organizational performance can be used to evaluate whether the work process undertaken by the organization has been in line with the expected goals or not. However, in reality there are many organizations that are lacking or even rarely have information about performance in their organizations. Gibson et al. (2003) stated performance as the outcome of job which relates to the purpose of the organization such as quality, efficiency and any other criteria of effectiveness. It can be stated that organizational performance is the final achievement of an organization and contains several things; such as the existence of certain targets achieved, having a period of time in achieving targets and achieving efficiency and effectiveness.

To assess organizational performance, of course, indicators or criteria are needed to measure it clearly. Without clear indicators and criteria there will be no direction that can be used to determine which are relatively more effective among: different alternative resource allocations; alternative organizational designs that are different; and among the choices of distributing different tasks and authorities. There are indicators that are often used to measure the performance of private/public organizations such as: workload/domain, economy, efficiency, effectiveness and productivity (Hubeis, 2012). Stakeholders from public organizations often have interests that clash with one another. As a result the size of the performance of public organizations in the eyes of stakeholders also becomes different. This study uses the concept of measuring organizational performance only from the aspect of financial perspective. The financial ratio used is the ratio of liquidity, activity, profitability and leverage.

\section{Methodology ReSEARCH}

\subsection{Research approach and research location}

The research approach used is a qualitative approach and a quantitative approach. In connection with this, data collection is carried out by: library research refers to theoretical books, published company annual reports, company websites, newspaper clippings, and other magazines. Data used in this case are historical data, data taken from the financial statements of the best consumer goods company in 2016, 2017 and 2018 which are publicly published and publications made by the Indonesia Stock Exchange (IDX). Field research is carried out through observation or direct observation and interviews (FGD) This research was conducted at the top four Indonesia Most Admired Companies 2018 in consumer goods category; PT Garuda Food Putra Putri Jaya (PT. GFPPJ),PT Gudang Garam (PT. GG),PT Indofood Sukses Makmur(PT.ISM) and PT Unilever Indonesia (PT. UI).

\subsection{Concept Definition and Key Components for Assessing Competing Position of the Company}

The company's competitive position can be seen from the company's performance, in this study performance is measured by financial performance. To measure and analyze the company's financial performance, a valuation component is used as shown in Table 3.1 below.

Table 3.1. Concept Definitions and Key Components of Performance Assessment

\begin{tabular}{|c|c|c|c|c|}
\hline No & $\begin{array}{c}\text { Key } \\
\text { Compo } \\
\text { nents }\end{array}$ & $\begin{array}{c}\text { Type of } \\
\text { Standard } \\
\text { Ratio }\end{array}$ & Concept Definition & $\underset{d}{\text { Standar }}$ \\
\hline \multirow{4}{*}{2} & \multirow[t]{4}{*}{$\begin{array}{l}\text { Likwidit } \\
\mathrm{y} \\
\text { Aktivity }\end{array}$} & $\begin{array}{l}\text { 1. Current } \\
\text { Ratio (CR) } \\
\\
\text { 2. Quick } \\
\text { Ratio (QR) }\end{array}$ & $\begin{array}{l}\text { How much current assets } \\
\text { are available to cover } \\
\text { short-term liabilities or } \\
\text { debts that are } \\
\text { immediately due date } \\
\text { How many current assets } \\
\text { are available to cover } \\
\text { short-term liabilities or } \\
\text { debts that are } \\
\text { immediately due date } \\
\text { without taking into } \\
\text { account the value of } \\
\text { inventory }\end{array}$ & $150 \%$ \\
\hline & & $\begin{array}{l}\text { 1. Inventor } \\
\text { y Turn Over } \\
\text { (ITO) }\end{array}$ & $\begin{array}{l}\text { The ratio used to } \\
\text { measure the number of } \\
\text { times the funds planted } \\
\text { in inventory revolve in a } \\
\text { period. }\end{array}$ & $20 x$ \\
\hline & & $\begin{array}{l}\text { 2. Fixed } \\
\text { Asset Turn } \\
\text { Over (FATO) }\end{array}$ & $\begin{array}{l}\text { The ratio used to } \\
\text { measure the number of } \\
\text { times the funds invested } \\
\text { in fixed assets revolve in } \\
\text { one period. In other } \\
\text { words, to measure } \\
\text { whether the company } \\
\text { has used the full capacity } \\
\text { of fixed assets or not. }\end{array}$ & $5 x$ \\
\hline & & $\begin{array}{c}\text { 3. Total } \\
\text { Asset Turn } \\
\text { Over (TATO) }\end{array}$ & $\begin{array}{l}\text { Is a ratio used to measure } \\
\text { the turnover of all assets } \\
\text { owned by the company } \\
\text { and measure how many } \\
\text { sales are obtained from } \\
\text { each rupiah of assets. }\end{array}$ & $2 \mathrm{x}$ \\
\hline \multirow[t]{2}{*}{3} & \multirow[t]{2}{*}{$\begin{array}{l}\text { Profitab } \\
\text { ility }\end{array}$} & $\begin{array}{l}\text { 1. Gross } \\
\text { Profit Margin } \\
(\mathrm{GPM})\end{array}$ & $\begin{array}{l}\text { Profit that is relative to } \\
\text { the company, by means } \\
\text { of net sales minus the } \\
\text { cost of goods sold. This } \\
\text { ratio is the way to } \\
\text { determine the cost of } \\
\text { goods sold. }\end{array}$ & $30 \%$ \\
\hline & & $\begin{array}{l}2 . \quad \text { Net } \\
\text { Profit Margin } \\
(\mathrm{NPM})\end{array}$ & $\begin{array}{l}\text { It is a measure of profit } \\
\text { by comparing earnings } \\
\text { after the interest and tax } \\
\text { compared to sales:nthis } \\
\text { ratio shows the } \\
\text { compasy's net income } \\
\text { from sales. }\end{array}$ & $20 \%$ \\
\hline & $\begin{array}{l}\text { Publish } \\
\text { Blue Ey } \\
\text { \& Scien }\end{array}$ & blication & & \\
\hline
\end{tabular}




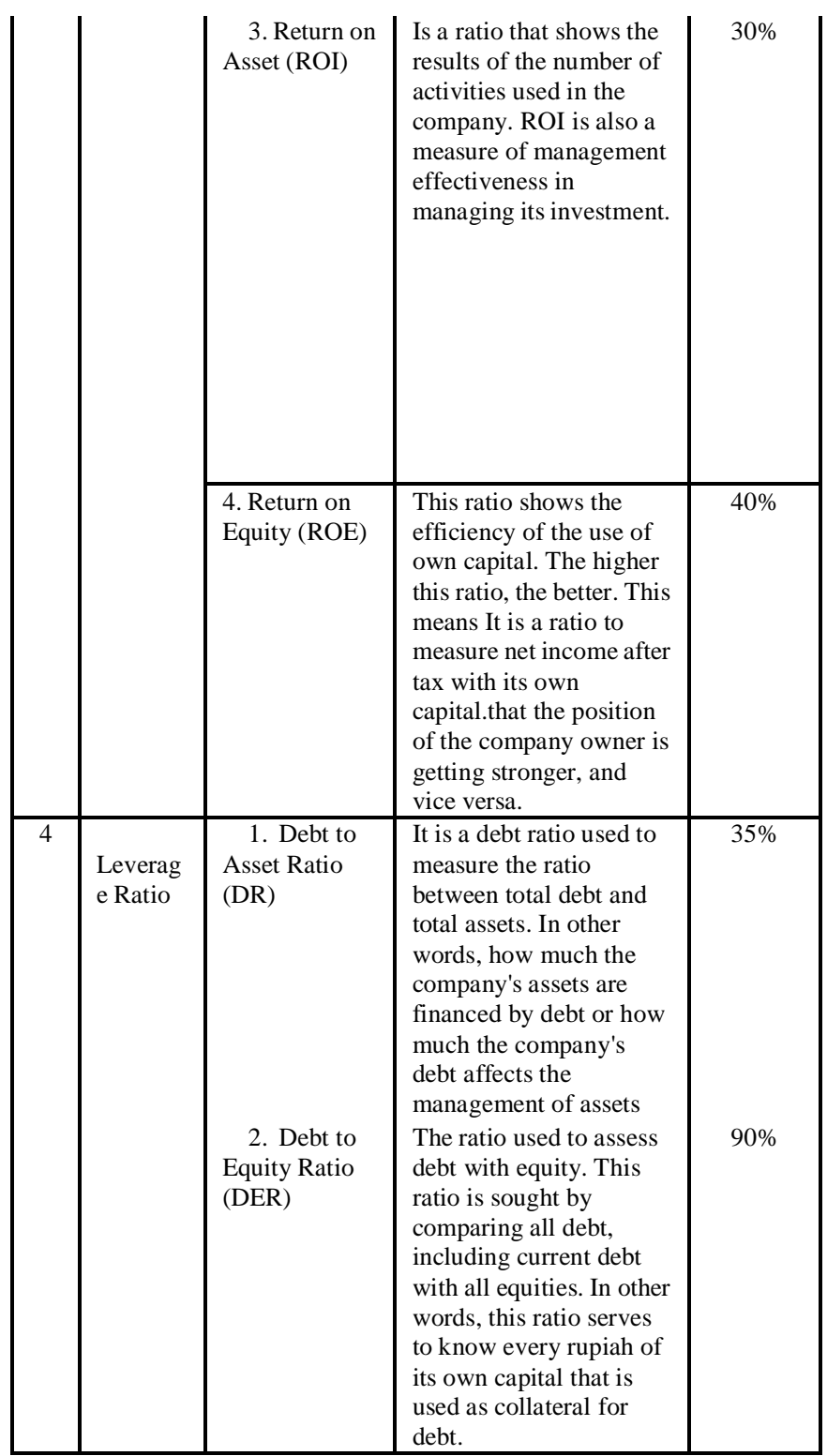

\subsection{Variables that map the axis of the SPACE matrix}

To find out the company's strategy through the SPACE Matrix, several variables need to be analyzed. Table 3.2 below presents variables that map the SPACE-Matrix axis.

Table 3.2. Variables that map the SPACE Matrix Axis

\begin{tabular}{|l|l|}
\hline \multicolumn{1}{|c|}{$\begin{array}{c}\text { Internal Strategic } \\
\text { Position }\end{array}$} & \multicolumn{1}{c|}{$\begin{array}{c}\text { External Strategic } \\
\text { Position }\end{array}$} \\
\hline Financial Strength (FS) & $\begin{array}{l}\text { Environmental } \\
\text { Stability -ES }\end{array}$ \\
\hline $\begin{array}{c}\text { - Return of investment } \\
\text { (ROI) }\end{array}$ & - Technological changes \\
- Financial and operating & - Inflation \\
leverage & - Demand elasticity \\
- Liquidity & - Competitor's price \\
- Working capital & ranges \\
- Cash flows & - Barriers to entry \\
- Inventory Turnover & - Competitive pressure \\
- Earning/share & - Ease of exit \\
\hline Competitive Advantage- & Industry Strength-IS \\
CA & \\
\hline
\end{tabular}

\begin{tabular}{|l|l|}
\hline - Market Share & - Growth potential \\
- Quality & - Profit potential \\
- Product Life Cycle & - Financial stability \\
- Customer Prefference & Resource availability \\
- Technological Inovation & - Ease of entry \\
- Sound Supply Chain & - Capacity utilization \\
\hline
\end{tabular}

Source: David, 2009

\subsection{Data analysis method}

Research methods include qualitative and quantitative studies. Quantitative analysis of the research comes from the financial statements of company publications for the period December 2016, 2017 and 2018 and other secondary data. While qualitative methods to identify critical success factors take data from newspaper clippings, bank internal bulletins, interviews and ask for opinions from experts (FGD). SPACE Matrix Analysis is carried out through organizational performance indicators, and SPACE Matrix analysis. To assess organizational performance the steps of data analysis are as follows:

- Calculation of financial ratios with time series analysis methods

- Comparing financial performance

- Draw conclusions from the calculation of financial ratios

To find out the company's strategy is done by the following steps: The steps needed to develop the Strategic Position and Action Evaluation Matrix (SPACE-Matrix) are:

1) Determine variables to define financial strength (FS), competitive advantage (CA), environmental stability (ES) and industrial strength (IS)

2) Give values ranging from +1 (worst) to +6 (best) for each dimension of FS and IS; Give values ranging from -1 (best) to -6 (worst) for each ES and CA dimension.

3) Calculate the average value for FS, CA, IS and ES by summing the values given to the variables of each dimension and then dividing by the number of variables included in that dimension

4) Place the average value for FS, IS, ES and CA for the corresponding axis in the SPACE matrix

5) Add two values for the $X$ axis and the result point image on $\mathrm{X}$. Add two values for the $\mathrm{Y}$ axis and the result point image on Y. The intersection of the new XY point

6) Image of the direction vector from the origin of the SPACE matrix through the new intersection point. This vector reveals the types of strategies recommended for organizations:Aggressive, Competitive, Defensive or Conservative.

\section{RESULTS AND FINDINGS}

\subsection{Identification of Corporate Financial Performance}

The financial performance of a company can be assessed based on financial statement analysis and financial ratio analysis of the company concerned. In this study, the key components of the valuation of financial performance used are the Liquidity Ratio (Current Ratio, Quick Ratio), Activity Ratio (Inventory Turn Over, Total Assets Turn Over, Fixed Assets Turn

Over); Profitability Ratio (Gross Profit Margin, Net Profit Margin, Return On

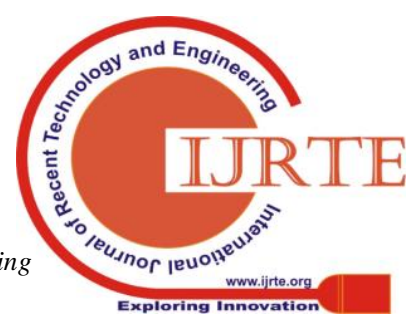


Investment, Return On Equity) and Leverage Ratio (Debt Ratio, Debt to Equity Ratio). The financial performance of consumer goods company in 2016, 2017 and 2018 is presented in Table 4.1. While the average financial ratio is presented in Table 4.2.

Table 4.1. Corporate Financial Performance of Consumer Goods

\begin{tabular}{|c|c|c|c|c|c|c|c|c|c|c|}
\hline \multirow{3}{*}{$\begin{array}{c}\text { Ty } \\
\text { pe } \\
\text { of } \\
\text { rati } \\
\text { o }\end{array}$} & \multirow{3}{*}{$\begin{array}{c}\text { Sta } \\
\text { n } \\
\text { dar } \\
\text { d }\end{array}$} & \multirow{2}{*}{\multicolumn{3}{|c|}{$\begin{array}{c}\text { PT.GFPP } \\
\text { Year }\end{array}$}} & \multirow{2}{*}{\multicolumn{3}{|c|}{$\begin{array}{c}\text { PT.GG } \\
\text { Year } \\
\end{array}$}} & \multirow{2}{*}{\multicolumn{2}{|c|}{$\begin{array}{c}\text { PT. ISM } \\
\text { Year } \\
\end{array}$}} & \\
\hline & & & & & & & & & & \\
\hline & & $\begin{array}{c}201 \\
6\end{array}$ & $\begin{array}{c}201 \\
7\end{array}$ & $\begin{array}{c}201 \\
8\end{array}$ & 2016 & $\begin{array}{c}201 \\
7\end{array}$ & 2018 & $8 \begin{array}{r}201 \\
6\end{array} \mid$ & 2018 & \\
\hline CR & $\begin{array}{r}200 \\
\% \\
\end{array}$ & 116 & 101 & 133 & 193 & 193 & 199 & 15015 & \begin{tabular}{l|l}
52 & 147
\end{tabular} & \\
\hline $\mathrm{QR}$ & $\begin{array}{r}150 \\
\% \\
\end{array}$ & 56 & 52 & 96 & 20 & 25 & 29 & 10510 & \begin{tabular}{l|l}
07 & 103
\end{tabular} & \\
\hline TO & $\begin{array}{r}20 \\
\mathrm{X}\end{array}$ & 6.40 & 7.61 & 13.40 & 1.60 & 1.72 & 1.50 & 5.804. & 103.88 & \\
\hline $\begin{array}{c}\Gamma A \\
\mathrm{~T} \\
\mathrm{O}\end{array}$ & $2 x$ & 2.07 & 2.09 & 90.66 & 1.21 & 1.24 & 1.04 & 0.790. & 790.80 & \\
\hline $\begin{array}{c}\mathrm{FA} \\
\mathrm{T} \\
\mathrm{O}\end{array}$ & $5 x$ & 2.07 & 2.09 & 90.66 & 3.62 & 3.62 & 2.99 & 0.800. & 790.78 & \\
\hline $\begin{array}{r}\mathrm{GP} \\
\mathrm{M} \\
\end{array}$ & $\begin{array}{r}30 \\
\% \\
\end{array}$ & \begin{tabular}{|r|}
28.2 \\
7 \\
\end{tabular} & $\begin{array}{c}32.3 \\
8 \\
\end{array}$ & $\begin{array}{r}33.3 \\
8 \\
\end{array}$ & \begin{tabular}{|c}
21.7 \\
8 \\
\end{tabular} & \begin{tabular}{|c|}
21.8 \\
7 \\
\end{tabular} & $\begin{array}{c}19.6 \\
2 \\
\end{array}$ & 2928 & \begin{tabular}{c|c}
8.3 & 46.2 \\
0 & 2 \\
\end{tabular} & \\
\hline $\begin{array}{r}\mathrm{NP} \\
\mathrm{M}\end{array}$ & $\begin{array}{c}20 \\
\%\end{array}$ & 9.48 & 5.03 & 37.67 & 8.74 & 9.30 & 8.24 & 4.26 & \begin{tabular}{l|l}
.1 & 9.25
\end{tabular} & \\
\hline $\begin{array}{c}\mathrm{RO} \\
\mathrm{I}\end{array}$ & $\begin{array}{c}30 \\
\%\end{array}$ & $\begin{array}{c}19.6 \\
5\end{array}$ & $\begin{array}{c}10.5 \\
5\end{array}$ & 5.09 & $\begin{array}{c}10.5 \\
9\end{array}$ & $\mid \begin{array}{c}11.6 \\
1\end{array}$ & 8.63 & 6.106 & 807.30 & \\
\hline $\begin{array}{r}\mathrm{RO} \\
\mathrm{E}\end{array}$ & $\begin{array}{r}40 \\
\%\end{array}$ & $\begin{array}{c}52.8 \\
1\end{array}$ & $\begin{array}{c}29.8 \\
6\end{array}$ & 89.77 & $\begin{array}{c}16.8 \\
6\end{array}$ & \begin{tabular}{|c|}
18.3 \\
8
\end{tabular} & $\begin{array}{c}13.4 \\
2\end{array}$ & 12.111 & \begin{tabular}{l|c}
1.3 & 13.9 \\
4
\end{tabular} & \\
\hline DR & $\begin{array}{r}35 \\
\% \\
\end{array}$ & \begin{tabular}{|c|}
62.7 \\
9 \\
\end{tabular} & $\begin{array}{c}65.3 \\
6 \\
\end{array}$ & $\begin{array}{r}348.0 \\
5 \\
\end{array}$ & $\begin{array}{c}37.1 \\
5 \\
\end{array}$ & $\begin{array}{c}36.8 \\
0 \\
\end{array}$ & \begin{tabular}{|r}
35.6 \\
9 \\
\end{tabular} & \begin{tabular}{r|r}
46.3 & 46 \\
9 & \\
\end{tabular} & \begin{tabular}{c|c}
6.7 & 47.5 \\
1 & 7 \\
\end{tabular} & \\
\hline $\begin{array}{r}\mathrm{DE} \\
\mathrm{R} \\
\end{array}$ & $\begin{array}{r}90 \\
\%\end{array}$ & 169 & 183 & 92 & $\begin{array}{c}59.1 \\
1\end{array}$ & $\begin{array}{c}58.2 \\
4 \\
\end{array}$ & $\begin{array}{r}55.4 \\
9 \\
\end{array}$ & \begin{tabular}{|r|r|}
86.3 & 87 \\
3 & \\
\end{tabular} & $\begin{array}{cc}7.6 & 90.7 \\
7 & 5 \\
\end{array}$ & \\
\hline Joo & D & & $p$ & 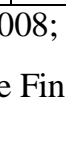 & 1 & 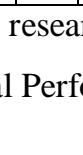 & & 1 & & \\
\hline $\begin{array}{r}\text { Typ } \\
\text { of } \\
\text { Rat }\end{array}$ & & $\begin{array}{r}\text { Stand } \\
\text { d }\end{array}$ & & $\begin{array}{r}\text { PT. } \\
\text { P }\end{array}$ & & $\begin{array}{r}\text { PT. } \\
\text { G }\end{array}$ & & $\begin{array}{c}\text { PT. } \\
\text { ISM }\end{array}$ & $\begin{array}{c}\text { PT. } \\
\text { UI }\end{array}$ & \\
\hline $\mathrm{CF}$ & & $200^{\circ}$ & & 116 &, 67 & 195 & & 149.67 & 80.30 & \\
\hline $\mathrm{QF}$ & & $150^{\circ}$ & & & 3,00 & 24,6 & & 105.20 & 47.33 & \\
\hline ITR & & $20 x$ & & 5 , & 80 & 1,61 & & 4.59 & 7.78 & \\
\hline $\begin{array}{r}\text { TA } \\
\mathrm{O}\end{array}$ & & $2 \mathrm{x}$ & & 1, & 61 & 1.10 & & 0.79 & 2.04 & \\
\hline $\begin{array}{r}\text { FA } \\
\mathrm{O} \\
\end{array}$ & & $5 x$ & & 1, & 61 & 3.41 & & 0.79 & 0.59 & \\
\hline GP & & $30 \%$ & & 31 & 34 & 21.0 & & 34.51 & 50.75 & \\
\hline NPI & & $20 \%$ & & 7, & & 8.70 & & 6.52 & 18.71 & \\
\hline $\mathrm{RO}$ & & $30 \%$ & & 11 & 76 & 10.2 & & 6.73 & 38.41 & \\
\hline $\mathrm{RO}$ & & $40 \%$ & & 30 & 81 & 16.2 & & 12.45 & 117.54 & \\
\hline $\mathrm{DF}$ & & $35 \%$ & & 39 & 07 & 24.6 & & 46.89 & 66.57 & \\
\hline $\mathrm{DE}$ & & $90 \%$ & & 148 & 3,00 & 39.1 & & 88.25 & 214.81 & \\
\hline
\end{tabular}

Source: Kasmir, 2008; 2018 research results, processed

\subsection{Identification of Critical Success Factors (CSF)}

Consumer goods company in offering products to customers, of course, know the Critical Success Factor $(C S F)$ so that the product can be well-received. Critical success factors that must be considered. Based on references to books, theories, published company annual reports, company sites, then through direct observation or observation and focus group discussion $(F G D)$, interviews PT. $\mathbf{U}^{(F G D)}$ can be identified as critical success factors, ratings Year and weights. The critical success factors, ratings and weights are presented in Table 4.3.

201 Table 4.3 Matrix SPACE of consumer goods company

\begin{tabular}{||l|l|c|c|c|c|}
7 & CSF & $\begin{array}{c}\text { PT. } \\
\text { GFPP }\end{array}$ & PT. GG & $\begin{array}{c}\text { PT. } \\
\text { ISM }\end{array}$ & PT. UI \\
\hline
\end{tabular}

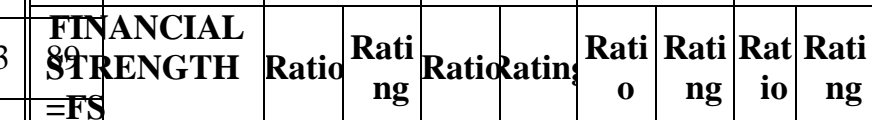

O5Return on

\begin{tabular}{|r|c|r|r|r|c|r|r|}
11.7 & 3 & 10.28 & 3 & 6.73 & 2 & 38.4 & 6 \\
6 & & & & & & 1 &
\end{tabular}
investment

8.48 6. 4 Return on

\begin{tabular}{|r|r|r|r|r|r|r|r|}
30.8 & 4 & 16.22 & 3 & 12.45 & 3 & 117. & 5 \\
\hline
\end{tabular}

\begin{tabular}{l||l|l|} 
& Equity \\
\cline { 2 - 3 } & 2.17 & $\begin{array}{l}\text { 1. Fross Profit } \\
\text { Margin }\end{array}$ \\
& & 31
\end{tabular}

\begin{tabular}{|r|l|l|l|l|l|r|r|}
1 & & & & & & 54 & \\
\hline 31.3 & 5 & 21.09 & 4 & 34.51 & 5 & 50. & 6 \\
4 & & & & & & 75 & \\
\hline
\end{tabular}

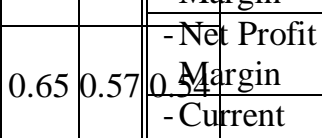

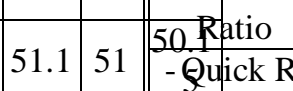

\begin{tabular}{|c|c|c|c|c|c|c|c|}
7.39 & 3 & 8.76 & 4 & 6.52 & 3 & 18.7 & 5 \\
\hline
\end{tabular}

\begin{tabular}{l|l||r|}
5.9 & 17.0 & 23.1 \\
\hline & &
\end{tabular}

$6011-$ - 6 yyentory

3 36.5nn Over

\begin{tabular}{|c|c|c|c|c|c|c|c|}
\hline 116. & 4 & 195 & 6 & 149.6 & 5 & 80.3 & 3 \\
\hline
\end{tabular}

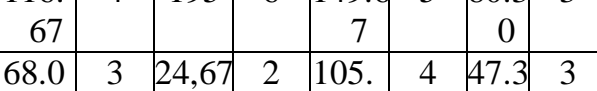

\begin{tabular}{|r|l|l|l|c|r|r|r}
0 & & & & 20 & & 3 & \\
\hline 5.80 & 3 & 1,61 & 2 & 4.59 & 3 & 7.78 & 4
\end{tabular}

1.61

\begin{tabular}{l|l|l|l|l|l|l|l|}
1.61 & 3 & 1.16 & 3 & 0.79 & 2 & 2.04 & 5
\end{tabular} 5. 135. 81 14 1 Over

\begin{tabular}{|l|l|l|l|l|l|l|l|l|} 
& & & & & & & & \\
\hline
\end{tabular}

972.6 55.1 1 . Over

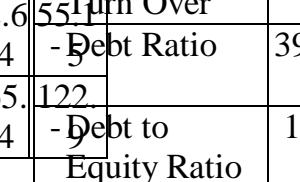

\begin{tabular}{|l|l|l|l|l|l|l|l|}
39.0 & 5 & 24.65 & 3 & 46.89 & 2 & 66.5 & 2 \\
\hline
\end{tabular} \begin{tabular}{|r|r|r|r|r|r|r|r|}
\hline 148 & 3 & 39.12 & 4 & 88.25 & 4 & 214 & 2 \\
\hline
\end{tabular}

\begin{tabular}{|c|c|c|c|c|}
\hline Equity Ratio & & & & 81 \\
\hline $\begin{array}{c}\text { Total } \\
\text { Average of } \\
\text { FS }\end{array}$ & $\begin{array}{l}39 \\
3.5\end{array}$ & $\begin{array}{c}1 \\
38 \\
3.45\end{array}$ & $\begin{array}{c}1 \\
35 \\
3.18\end{array}$ & $\begin{array}{l}43 \\
3.9\end{array}$ \\
\hline $\begin{array}{l}\text { INDUSTRIA } \\
\text { L } \\
\text { STRENGH } \\
=\text { IS }\end{array}$ & Rating & Rating & Rating & Rating \\
\hline $\begin{array}{l}\text {-Growth } \\
\text { potential }\end{array}$ & 6 & 4 & 4 & 5 \\
\hline $\begin{array}{l}\text {-Profit } \\
\text { potential }\end{array}$ & 5 & 4 & 4 & 5 \\
\hline $\begin{array}{l}\text { - Financial } \\
\text { stability }\end{array}$ & 4 & 4 & 5 & 4 \\
\hline $\begin{array}{l}\text { - Resource } \\
\text { availability }\end{array}$ & 5 & 4 & 4 & 3 \\
\hline - Ease of entry & 5 & 4 & 4 & 5 \\
\hline $\begin{array}{l}\text { - Capacity } \\
\text { utilization }\end{array}$ & 4 & 4 & 4 & 4 \\
\hline $\begin{array}{c}\text { Total } \\
\text { Average of } \\
\text { IS } \\
\end{array}$ & $\begin{array}{c}29 \\
4.83\end{array}$ & $\begin{array}{c}24 \\
4\end{array}$ & 25 & $\begin{array}{l}26 \\
4.33\end{array}$ \\
\hline
\end{tabular}




\begin{tabular}{|c|c|c|c|c|}
\hline $\begin{array}{l}\text { ENVIRONME } \\
\text { NTAL } \\
\text { STABILITY= } \\
\text { ES }\end{array}$ & & & & \\
\hline $\begin{array}{l}\text { - Technologic } \\
\text { al changes }\end{array}$ & -2 & -2 & -2 & -3 \\
\hline -Inflation & -3 & -3 & -3 & -3 \\
\hline $\begin{array}{l}\text { - Demand } \\
\text { elasticity }\end{array}$ & -3 & -5 & -4 & -2 \\
\hline $\begin{array}{l}\text { - Competitor's } \\
\text { price ranges }\end{array}$ & -2 & -3 & -3 & -4 \\
\hline -Ease of exit & -3 & -3 & -3 & -3 \\
\hline $\begin{array}{l}\text {-Price } \\
\text { elasticity of } \\
\text { demand }\end{array}$ & -3 & -4 & -3 & -2 \\
\hline $\begin{array}{l}\text { - Risk } \\
\text { exposure }\end{array}$ & -3 & -5 & -5 & -2 \\
\hline $\begin{array}{c}\text { Total } \\
\text { Average of } \\
\text { Environment } \\
\text { al Stability }\end{array}$ & $\begin{array}{l}-19 \\
-2.71\end{array}$ & $\begin{array}{c}-25 \\
-3.57\end{array}$ & $\begin{array}{c}-23 \\
-3.28\end{array}$ & $\begin{array}{l}-19 \\
2.7\end{array}$ \\
\hline \multicolumn{5}{|l|}{$\begin{array}{l}\text { COMPETITI } \\
\text { VE } \\
\text { ADVANTAG } \\
\text { E=CA }\end{array}$} \\
\hline $\begin{array}{l}\text {-Market } \\
\text { Share }\end{array}$ & -3 & -3 & -3 & -2 \\
\hline -Quality & -4 & -5 & -4 & -3 \\
\hline $\begin{array}{l}\text { - Product Life } \\
\text { Cycle }\end{array}$ & -4 & -4 & -3 & -2 \\
\hline $\begin{array}{l}\text { - Customer } \\
\text { Prefference }\end{array}$ & -1 & -4 & -1 & -3 \\
\hline $\begin{array}{l}\text { - Technologic } \\
\text { al Inovation }\end{array}$ & -4 & -5 & -4 & -4 \\
\hline $\begin{array}{l}- \text { Sound } \\
\text { Supply } \\
\text { Chain }\end{array}$ & -2 & -4 & -2 & -2 \\
\hline Total & -18 & -25 & -17 & -16 \\
\hline $\begin{array}{c}\text { Average of } \\
\text { CA }\end{array}$ & -3 & -4.16 & -2.83 & -2.67 \\
\hline
\end{tabular}

Source : David, 20 ; 2018 research results, processed

\subsection{Competitive position based on financial performance}

Financial performance analysis is basically made to see the prospects and risks of the company. Prospects can be seen from the level of profit (profitability) and risk can be seen from the possibility of companies experiencing financial difficulties or bankruptcy. Based on the identification of the financial performance of consumer goods company on the key components of the assessment used, the comparison can be seen as follows.

\subsubsection{Likuidity Ratio}

The liquidity ratio shows the company's ability to meet short-term financial obligations, such as paying salaries, maturing debt, operating costs, and others. The following is a ratio that is often used to calculate liquidity ratios.

\section{Current Ratio}

Current Ratio shows the comparison of current assets with current liabilities. The higher the ratio, the better the liquidity. If the number of current ratio of a company is more than $100 \%$, then the company has good ability in paying off its obligations because the comparison of assets is proportional to the obligations they have. The good standard ratio is $200 \%$. Figure 4.1 shows that the Current Ratio of PT GG is the best, followed by PT.ISM, then PT. GFPPJ and PT. UI. The worst current ratio is PT. ISM with CR below $100 \%$, meaning that its ability to pay off debt is still questionable.

\section{- Quick Ratio}

Quick ratio shows a comparison between (cash + short-term securities + accounts receivable) with current liabilities. In other words, the amount of balance between current assets minus inventory with current debt. The quick ratio is also commonly called the acid test ratio. Inventory is not included in the calculation of this ratio because inventory is a current asset that has a small level of liquidity. The higher the result, the better the liquidity. If the quick ratio is more than $100 \%$, then it shows the company's ability to fulfill its obligations, but if the value is above $300 \%$ then it does not mean that the condition of the company's liquidity is better. It may be that the company's cash is large because it is not allocated anywhere or because of the company's high receivables. Quick ratio can be used as a better reference because it focuses on current assets that are easily converted into cash. A good standard for this ratio is $150 \%$. Figure 4.2 shows that the best quick ratio is PT. ISM, which is above $100 \%$ followed by PT. GFPPJ, PT. UI and PT. GG. The two companies with the worst quick ratio are PT. UI and PT. GG with a ratio below $100 \%$.

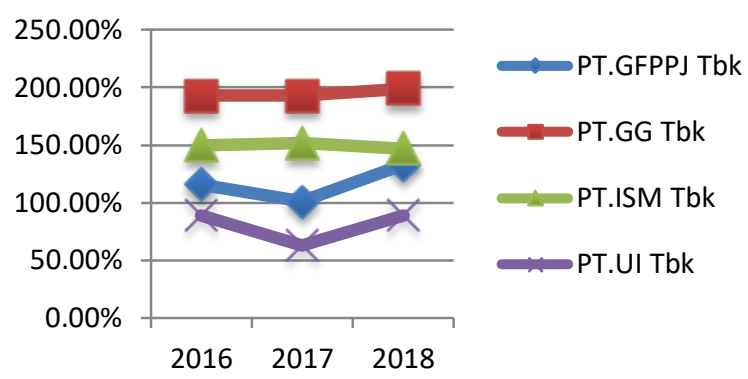

Figure 4.1. Current Ratio

Source: 2016, 2017, 2018 Annual Financial Report, processed

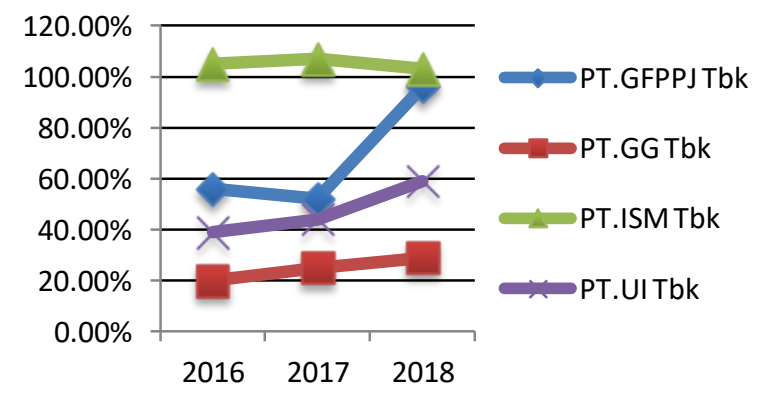

Figure 4.2. Quick Ratio

Source: 2016, 2017, 2018 Annual Financial Report, processed 


\subsubsection{Activity Ratio}

This ratio measures the level of use of company assets or assets, which assets are productive and which assets are less productive. Thus, it can decide on a larger allocation of funds for productive assets. The following is a ratio that is often used to calculate the activity ratio.

\section{- Inventory Turn Over}

Inventory turnover is a measure of how efficiently a company can control its merchandise or inventory. The higher the turnover ratio the more efficient the company is in controlling its inventory. A high turnover ratio indicates that the company does not pay too much to buy its merchandise. It can avoid wastage of company resources if the inventory does not sell as expected. A high inventory turnover ratio also shows that the company can effectively sell the inventory it buys. If it is low, it means the effectiveness of inventory control is not good. A good standard for this ratio is 20 times. Figure 4.3 shows that PT. UI has the best Inventory Turn Over (ITO), followed by PT. GFPPJ, PT. ISM and PT. GG. If it is judged from a good ITO ratio standard (20 times), the actual number of ITO owned by the four consumer goods company is still far from expected. Thus, it can be concluded that this consumer goods company has not been able to effectively sell its inventory.

\section{- Total Asset Turn Over}

This ratio is almost the same as the fixed asset turnover ratio, which distinguishes it is the divider used, namely total assets. This ratio is used to calculate the effectiveness of total asset usage. The higher the turnover, the more effective the company is in use total assets for its sales. A good standard for this ratio is two times. Figure 4.4 shows that PT. UI still has the best Total Asset Turn Over (TATO), followed by PT. GFPPJ, PT. GG and PT. ISM. If it is judged from a good TATO ratio standard. The TATO numbers owned by these four consumer goods company are good, such as the TATO numbers owned by PT UI and PT. GGPPJ which have reached the standard. Thus, it can be concluded that in general this consumer goods company has been able to effectively manage total assets.

\section{- Fixed Asset Turn Over}

This ratio measures the extent to which a company's ability to generate sales with its fixed assets. The bigger the ratio, the better for the company. This ratio is quite important for industries that have high fixed assets. Whereas for industries with small assets such as service companies, it becomes less important. A good standard for this ratio is 5 times. Figure 4.5 shows that PT. GG has the best Fixed Asset Turn Over (FATO), followed by PT. GFPPJ, PT. ISM and PT. UI. However, none of these companies met good ratio standards. Thus it can be concluded that the company in general has not been able to manage its fixed assets in an effort to generate sales.

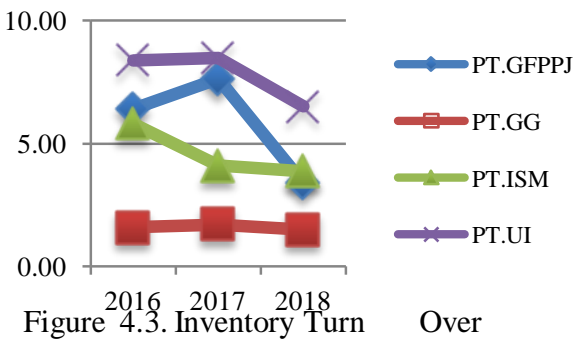

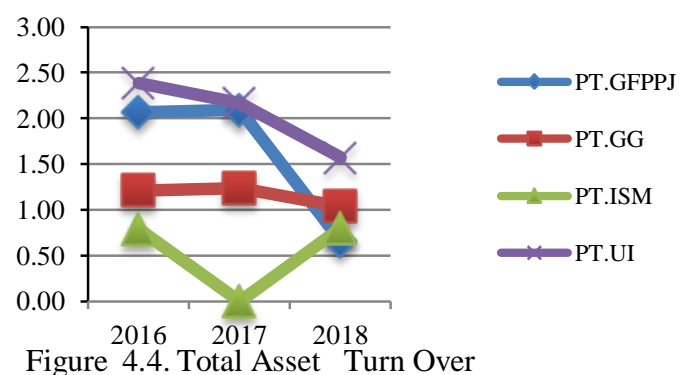

Figure 4.4. Total Asset Turn Over

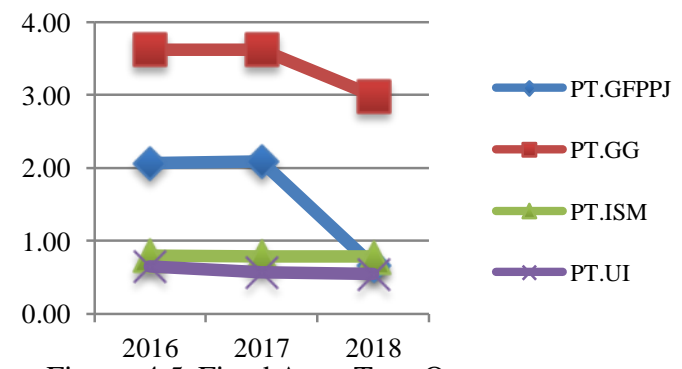

Figure 4.5. Fixed Asset Turn Over

\subsubsection{Profitability Ratio}

The profitability ratio shows the company's ability to make a profit. Profitability ratio is needed for recording financial transactions. This ratio is needed by investors and creditors (banks) to assess the amount of investment profits that will be obtained by investors and the amount of corporate profits. The effectiveness and efficiency of management can be seen from the profits generated against sales and investment of companies seen from the elements of financial statements. The higher the ratio, the better the condition of the company based on profitability ratios. High values symbolize the level of profit and high company efficiency which can be seen from the level of income and cash flow. There are several measures that can be used to measure profitability ratios.

\section{- Gross profit margin}

Gross profit margin is a profitability ratio to assess the percentage of gross profit to income generated from sales. Gross profit margin measures the efficiency of calculating cost of goods or production costs. The higher the gross profit margin the better (efficient) the company's operational activities that show the cost of goods sold is lower than sales (sales) which is useful for operational audits. If the opposite, then the company is not good at carrying out operational activities. A good standard for this ratio is $30 \%$. Figure 4.6 shows that PT. UI has the best gross profit margin, this company meets well GPM ratio standards. Then, followed by PT. ISM and PT. GFPPJ. While those who are swept are PT. GG

\section{Net Profit Margin}

This ratio measures the rupiah amount of net income generated by every single rupiah sale. The higher the ratio means the better because it shows the company's ability to generate profits. A good standard for this ratio is 20\%. Figure 4.7 shows that PT. UI has the best net profit margin, this company well NPM ratio 
Then, followed by PT. GG, PT. ISM and PT. GFPP.

\section{- $\quad$ Return On Investment (ROI)}

Return on investment is a profitability ratio calculated from net income after tax deducted from total assets. Return on investment is useful to measure the ability of the company as a whole in generating profits against the total amount of assets available to the company. The higher this ratio means the better the condition of a company. A good standard for this ratio is $30 \%$. Figure 4.8 shows that the best return on investment is PT. UI meets a good ROI ratio standard. Then, followed by PT. GFPPJ, PT. GG, PT. ISM has the worst ROI ratio which that below $10 \%$.

\section{- Return On Equity (ROE)}

Return on Equity Ratio (ROE) is a profitability ratio to assess the company's ability to generate profits from the company's shareholder investment expressed in percentage. ROE is calculated from the company income on capital invested by company owners (ordinary shareholders and preferred shareholders). Return on equity shows how successful the company manages its capital (net worth) so that the level of profit is measured by the investment of the owner of the capital or the company's shareholders. ROE is the profitability of own capital or what is called, business profitability. A good standard for this ratio is $40 \%$. Figure 4.9 shows that the best return on equity is PT. UI meets a good ROI ratio standard. Then, followed by PT. GFPPJ, PT. GG and PT. ISM.

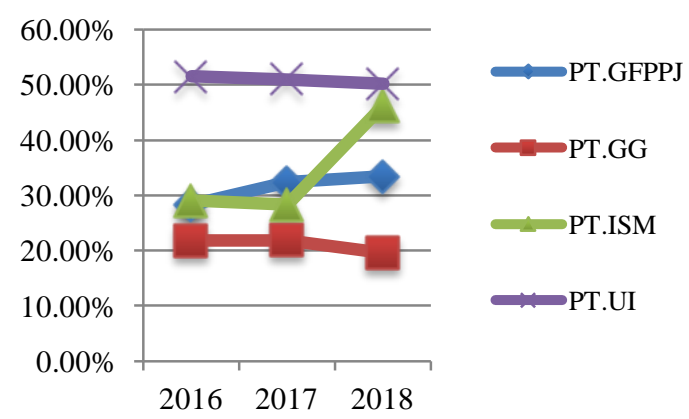

Figure 4.6. Gross Profit Margin

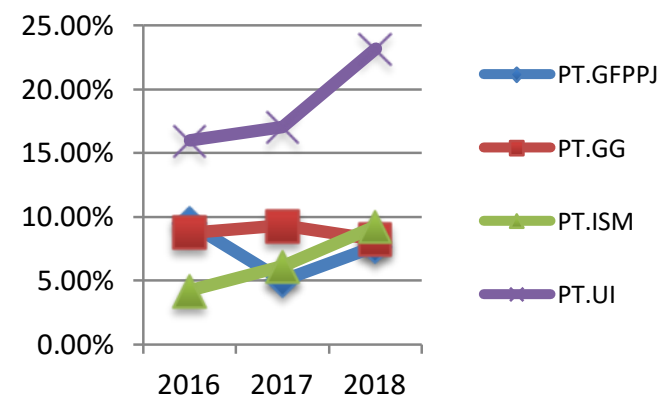

Figure 4.7. Net Profit Margin

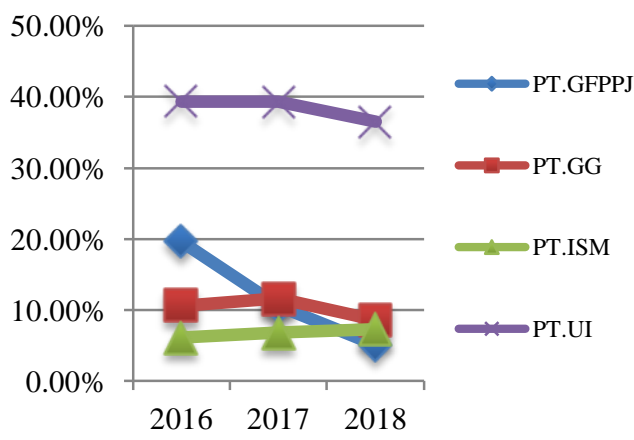

Figure 4.8. Return on Investment

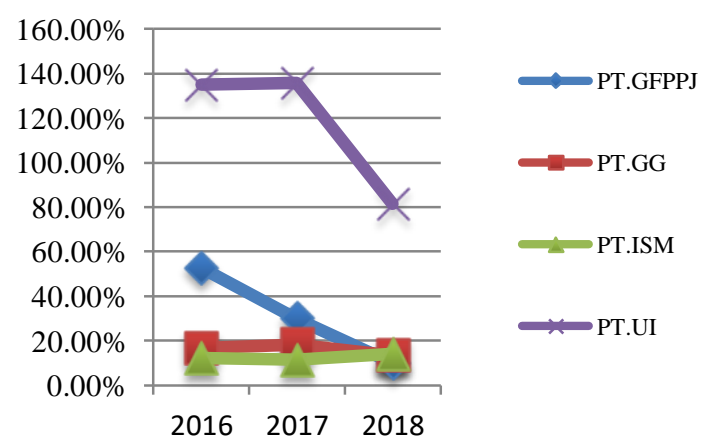

Figure 4.9. Return on Equity

\subsubsection{Leverage Ratio}

The leverage ratio shows the company's ability to fulfill all its obligations both long term and short-term if the company is liquidated. Companies that do not have sufficient assets to pay debts are usually called unsolvable companies. There are two ratios used to calculate it.

\section{- Total Debt to Total Assets Ratio}

This ratio is known as the debt ratio, which measures the amount of funds originating from debt. This ratio shows the extent to which debt can be covered by company assets. The smaller the ratio, the more safe the meal. Creditors will prefer the low debt ratio. It is better if the company's debt does not exceed the company's own capital. This is so that the fixed expenses incurred by the company are not high. The smaller the debt to capital, the better and safer. A good standard for this ratio is $35 \%$. Figure 4.10 shows that the best Total Debt to Total Assets Ratio is PT.GG. Then, followed by PT. ISM, PT. GFPPJ, and PT. UI.

\section{- Total Debt to Equity Ratio}

Comparison between debt and company equity which shows the ability of the own capital to fulfill all debts. Debt ratio with the own capital always pay attention to its position so that the debt held by the company with its own capital does not overlap. The higher the value of this ratio means less own capital compared to the debt that must be paid. The smaller the ratio, the better because the portion of debt to capital gets smaller so that the company's financial condition is more secure. Figure 4.11 shows that the best Total Debt to Equity Ratio is PT. GG. Then, PT. ISM, PT. GFPPJ, and PT. UI. 


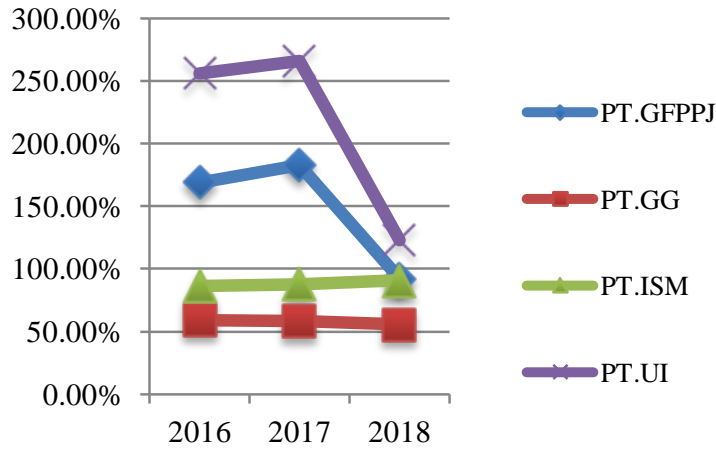

Figure 4.10. Debt to Equity Ratio

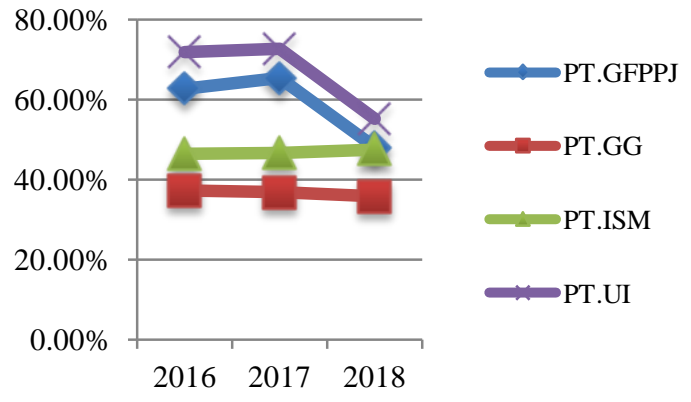

Figure 4.11. Debt to Asset Ratio

The results of the assessment of the financial performance of consumer goods company on the key components of the assessment used; it can be seen the competition position of the four companies. PT. UI is in the best position. The second is PT. GG, the third position is PT GFPP and the fourth is PT. ISM. The competition position is presented in Figure 4.12.

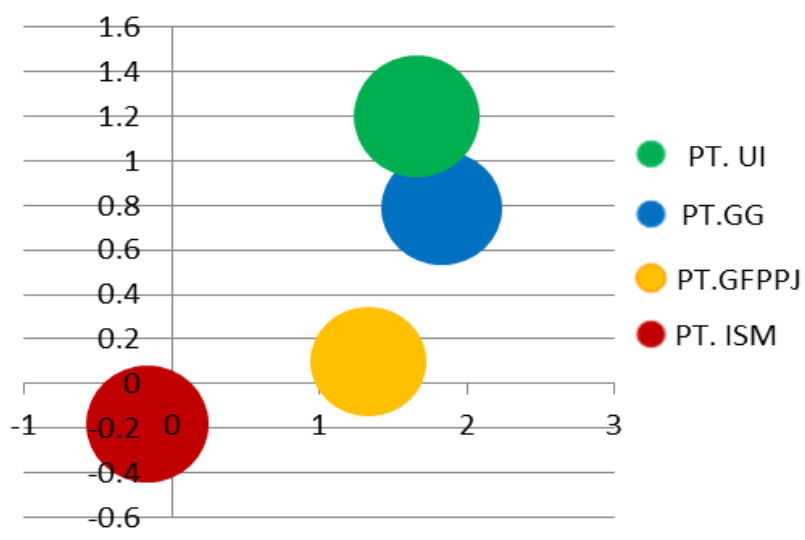

Figure 4.12. Position of competition for consumer goods company

\subsubsection{Strategy Analysis "Indonesia" Most Admired Companies (IMAC) 2018 "in Consumer Goods Category}

In essence there is no organization that has unlimited resources, the strategists must decide which alternative strategy will be the most profitable for the company. The decision formulation strategy encourages an organization to commit to specific products, markets, resources and technology over a long period of time.Long-term competitive determining strategy. David (2012) states that, important strategy formulation techniques can be integrated into a decision making framework with a matrix as a model of analysis. Tools in this framework can be applied to all sizes and types of organizations and can help the strategists identify, evaluate and choose the most appropriate strategy. Some of these techniques include SWOT-Matrix, SPACE-Matrix, BCG-Matrix, IE-Matrix, and Grand Strategy-Matrix. In this study, the position analysis framework and formulation of the strategies used are SPACE-Matrix.

Based on Table 4.3, SPACE Matrix of consumer goods company can find out the average value for two external dimensions and two internal dimensions that map the company's strategy. The dimensions that represent internal are Financial Strength (FS) and Competitive Advantage (CA), while the representative dimensions of External are Industrial Strength (IS) and Environmental Stability (ES). Table 4.6 presents the four-dimensional average values.

Table 4.6. Average Financial Strength (FS), Competitive Advantage (CA), Industrial Strength (IS) and Environmental Stability (ES) consumer goods company

\begin{tabular}{|c|c|c|c|c|c|}
\hline No & $\begin{array}{c}\text { Compa } \\
\text { ny } \\
\text { Name }\end{array}$ & $\begin{array}{c}\text { Financi } \\
\text { al } \\
\text { Strengt } \\
\text { h (FS) }\end{array}$ & $\begin{array}{c}\text { Industri } \\
\text { al } \\
\text { Strengt } \\
\text { h (IS) }\end{array}$ & $\begin{array}{c}\text { Environment } \\
\text { al } \\
\text { Stability(ES } \\
\text { ) }\end{array}$ & $\begin{array}{c}\text { Compettti } \\
\text { ve } \\
\text { Advantag } \\
\text { e (CA) }\end{array}$ \\
\hline 1 & $\begin{array}{c}\text { PT.GFP } \\
\text { P }\end{array}$ & 3.5 & 4.83 & -2.71 & -3 \\
\hline 2 & PT.GG & 3.45 & 4 & -3.57 & -4.16 \\
\hline 3 & PT.ISM & 3.18 & 4.16 & -3.28 & -2.83 \\
\hline 4 & PT.UI & 3.9 & 4.33 & -2.7 & -2.67 \\
\hline
\end{tabular}

Source; 2018 research results, processed

Based on the Average Value of Financial Strength (FS), Competitive Advantage (CA), Industrial Strength (IS) and Environmental Stability (ES) of consumer goods company, $\mathrm{X}$ Axis and $\mathrm{Y}$ Axis values can be calculated for the four companies. The $\mathrm{X}$ axis and $\mathrm{Y}$ Axis values are presented in Table 4.7.

Table 4.7. The Axis X and Y Axis values that map the company's strategy

\begin{tabular}{|c|l|r|r|}
\hline No & $\begin{array}{c}\text { Company } \\
\text { Name }\end{array}$ & X-Axis & Y-Axis \\
\hline 1 & PT.GFPP & 1.83 & 0.79 \\
\hline 2 & PT.GG & -0.16 & -0.18 \\
\hline 3 & PT.ISM & 1.33 & 0.10 \\
\hline 4 & PT.UI & 1.66 & 1.20 \\
\hline
\end{tabular}

Source; 2018 research results, processed

The vector image of the SPACE matrix through the intersection point is then obtained. This vector reveals the type of strategy recommended for the company, which is Aggressive, Competitive, Defensive or Conservative. Figure 4.13, namely the SPACE PT matrix. GFPP shows the strategic position, and at the same time informs the strategy profile that is appropriate for the company to implement. The company is in aggressive profile at coordinates $1.83 ; 0.79$ 


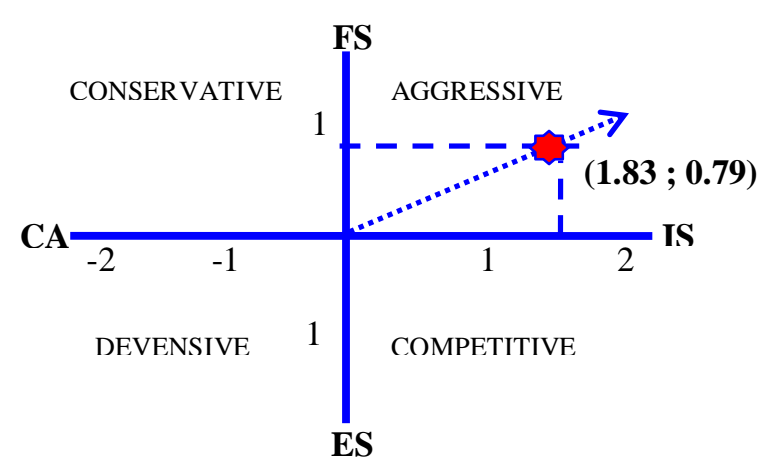

Figure 4.13. SPACE Matrix of PT.GFPP

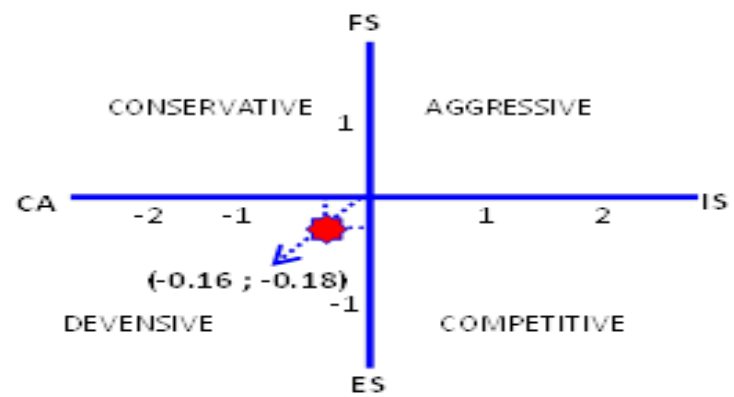

Figure 4.14. SPACE Matrix of PT.GG

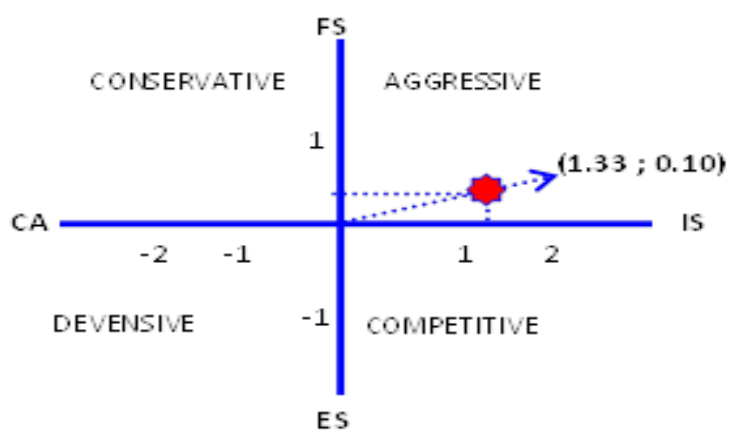

Figure 4.15. SPACE Matrix of PT.ISM

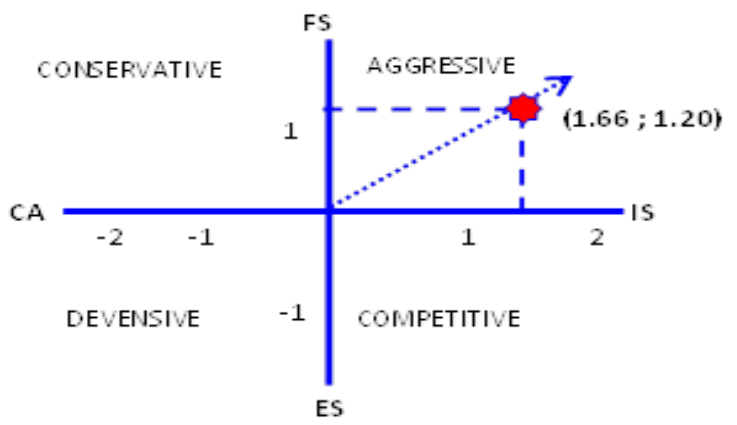

Figure 4.16. SPACE Matrix of PT.UI

Figure 4.14, namely matrix SPACE PT. $G G$ shows a strategic position, and at the same time informs the strategy profile that is appropriate for the company to implement. The company is on a positive profile at coordinates - 0.16 ; - 0.18. Figure 4.15 is matrix SPACE PT. ISM shows strategic position, and at the same time informs the strategy profile that is appropriate for the company to implement. The company is in the competitive profile at coordinates 1.33;- 0.10 . Figure 4.16, namely the SPACE matrix. PT. UI shows its strategic position, and at the same time informs the strategy profile that is appropriate for the company to implement. The company is on an aggressive profile at coordinates 1.66;1.2.

\section{CONCLUSION}

The position of competition based on the components of financial performance shows that PT. UI is in the best position. The secons is PT.GG, the third position is PT GFPP Tbk and the fourth is PT. ISM.

Based on SPACE mateikEssqueis, it is known that the right strategy to bq adopted by PT. GFPPJ, PT UI and PT. ISM is an aggressive strategy, while PT. GG is a defensive strategy.

\section{REFERENCES}

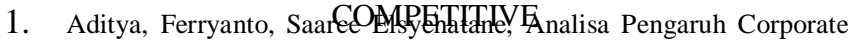
Image Terhadap Kinerja Keuangan Perusahaan Perbankan Di Surabaya, Business Accounting Review, Vol. 3, No. 2, Agustus 2015 : 91-100

2. Amir, Taufiq, 2008, Strategic Mindset, Membangun Fondasi Yang Kokoh Bagi Perencanaan Bisnis Anda, PT. Buana Populer, Kelompok Gramedia, Jakarta

3. David, Fred 2016. Manajemen Strategis, Konsep, Salemba Empat, Jakarta.

4. Dwiyanto, Agus, 1995. Penilaian Kinerja Organisasi Publik, Seminar kinerja Organisasi Sektor Publik, Kebijakan dan Penerapannya, Jurusan Ilmu Administrasi Negara, Fakultas Ilmu Sosial dan Politik, Universitas Gadjahmada, Yogjakarta $20 \mathrm{Mei}$

5. Gibson,James L, Ivancevich John M , Jr, Donnelly, James H, Konopaske Robert (2003). Organizations: Behavior, Structure, Processes, McGraw-Hill/Irwin

6. Grant, M Grant (2009). Analisis Strategi Kontemporer, Konsep, Teknik dan Aplikasi, Penerbit Erlangga, Jakarta.

7. Hitt, Michael A. (2001) Manajemen strategis : daya saing dan globalisasi konsep buku 1 Erlangga, Jakarta.

8. Hubeis, Musa \& Najib Mukhamad, 2012, Manajemen Strategik dalam pengembangan daya saing Organisasi, PT. Elex Media Komputindo, kelompok Gramedia, Jakarta.

9. Istanto, Yuni, Pengaruh Strategi Keunggulan Bersaing Dan Positioningterhadap Kinerja (Survey Pada Koperasi Serba Usaha Di Kabupaten Sleman Jogyakarta, Buletin Ekonomi Vol. 8, No. 2, Agustus 2010 hal 70-170

10. Nursya'bani Purnama , Hery Setiawan, Analisis Pengaruh Sumber-Sumber Keunggulan Bersaing Bidang Pemasaran Terhadap Kinerja Perusahaan Manufaktur Di Indonesia, JSB No. 8 Vol. 2, Desember 2003

11. Pearce, Robinson, Strategic Management (2012), 13th Edition, Mc Graw-Hill Education

12. Pefindo rating criteria \& methodology (2018) http://www.pefindo.com. April

13. Prasetyo, Caroline \& Gomies Benedicta, J. 2004. Perencanaan Strategi Map dengan Menggunakan Human Resource Scorecard pada Perusahaan Asuransi Bumi Asih Jaya Surabaya. Surabaya: Universitas Kristen Petra.

14. Simona Rus et al.(2016). Conceptualization and examination of success factors in the banking Procedia Economics and Finance ( 2016 ) $679-684$

15. Surfi, T. and Lyons, H. (2003).Mission statements exposed", International Journal of Contemporary Hospitality Management, 15 (4-5) - 255-262. 


\section{AUTHOR PROFILE}

I am Friska Sipayung, my affiliation is Faculty of Economics and Business, Universitas Sumatera Utara, Medan, Indonesia. My area of research is consumer behavior.

I am Liasta Ginting, currently I am associated with Faculty of Economics and Business, Universitas Sumatera Utara, Medan, Indonesia. My area of research is consumer behavior.

I am Magdalena Linda Leonita Sibarani, currently I am associated with Faculty of Economics and Business, Universitas Sumatera Utara, Medan, Indonesia. My area of research is consumer behavior. 